\title{
ANALIZA DRVENE GRAĐE SREDNJOVJEKOVNIH BRODICA IZ NINA
}

\author{
IRENA RADIĆ Rossi \\ Sveučilište u Zadru \\ Odjel za arheologiju \\ Obala kralja Petra Krešimira IV. 2 \\ HR-23000 Zadar \\ irradic@unizd.hr
}

\author{
Nili Liphschitz \\ Institute of Archaeology \\ The Botanical Laboratories \\ Tel Aviv University \\ IL-Tel Aviv \\ nilili@post.tau.ac.il
}

\author{
UDK: 904(497.5 Nin)"653":629.5 \\ Izvorni znanstveni članak \\ Original scientific paper \\ Primljeno / Received: 2010-11-02
}

\begin{abstract}
Krajem šezdesetih godina 20. stoljeća na ulazu u ninsku luku pronađeni su dobro očuvani ostatci dviju srednjovjekovnih brodica. Na inicijativu voditelja istraživanja Zdenka Brusića i konzervatora Božidara Vilhara oba su plovna objekta izvađena iz mora, konzervirana i izložena u Muzeju ninske baštine, čime je projekt zadobio sustavni karakter te donedavno predstavljao jedini arheološki projekt usmjeren na sustavno istraživanje i obradu podmorskih nalaza. Unatoč stručnim i znanstvenim radovima u kojima su brodovi sumarno obrađeni, detaljna objava nalaza tek predstoji. Stoga je 2008. započeo rad na dopuni postojeće dokumentacije, a jedan od prvih koraka bio je određivanje vrsta drvene građe korištene za izradu brodskih konstrukcija. U radu se ukratko iznose rezultati dosadašnjih istraživanja i provedenih analiza, te upozorava na alarmantno loše stanje nalaza.
\end{abstract}

KLJUČNE RIJEČI: brodica, srednji vijek, podmorsko istraživanje, analiza drvene građe, arheologija broda $i$ plovidbe

\section{Uvod}

U dnu Ninskoga zaljeva, na položaju zvanom Usta na ulazu u unutrašnju ninsku lagunu, prema podatcima pjeskara iz Privlake, krajem šezdesetih godina prošloga stoljeća Zdenko Brusić pronašao je dvije dobro očuvane srednjovjekovne brodice. ${ }^{1}$ Analizom radioaktivnog ugljika nalazi su datirani u 11./12. stoljeće, ${ }^{2}$ a prema zapisu Konstantina VII. Porfirogeneta, koji spominje hrvatsku flotu sastavljenu od manjih kondura i većih sagena, ${ }^{3}$ prozvani su kondurama. Pod tim nazivom predstavljeni su stručnoj i široj javnosti.

Entuzijazam istraživača i konzervatora, koji je u čitavoj Europi krajem šezdesetih i tijekom sedamdesetih godina doveo do naglog poleta podmorskih arheoloških istraživanja, potakao je realizaciju jedinog hrvatskog projekta tijekom kojeg su plovni objekti iz prošlosti podignuti s morskog dna, proučeni, konzervirani i prezentirani javnosti. ${ }^{4}$ Metodologija

\footnotetext{
${ }^{1}$ Z. BRUSIĆ, 1969; Z. BRUSIĆ, 1978, 5. Prema Pomorskom zakoniku (NN 181/04), čl. 5., brodicom se naziva plovni objekt koji nije jahta niti brod tj koji je duži od 2,5 i kraći od $12 \mathrm{~m}$. Takvu je definiciju korisno primijeniti i u slučaju arheoloških nalaza. U engleskom jeziku razlika se izražava primjenom termina boat i ship.
}

\footnotetext{
${ }^{2}$ Dva uzorka prove brodice analizirana su 1966., a tri uzorka druge brodice 1973. godine. D. SRDOČ, A. SLIJEPČEVIĆ, B. BREYER, 1971, 30; Z. BRUSIĆ, 1978, 11.

${ }^{3}$ Const. Porph. De admin. Imp., 31.

${ }^{4}$ Brodice su izložene u Muzeju ninske baštine (Arheološki muzej Zadar). M. KOLEGA, 2004.
} 
istraživanja arheologije broda i plovidbe ${ }^{5}$ u vrijeme ninskih otkrića tek se postupno oblikovala, pa su neki danas uvriježeni metodološki postupci u to vrijeme izostali. Kako je riječ o iznimno vrijednim nalazima koji su devedesetih godina, u svrhu promocije hrvatske kulturne i pomorske baštine, inspirirali i izradu dviju plovećih brodica, pokrenuta je inicijativa za objedinjavanjem postojeće dokumentacije i sustavnim proučavanjem brodskih konstrukcija po načelima suvremene metodologije. ${ }^{6}$ Prvi korak u tome smislu bila je analiza drvene građe, ostvarena tijekom mjeseca rujna i listopada 2008.

\section{KRATAK PREgLED REZULTATA PROJEKTA DO KRAJA 20. STOLJEĆA}

Prilikom vađenja pijeska u Ninskom zaljevu, pedesetih godina prošloga stoljeća, pjeskar Vjekoslav Kolanović iz Privlake primijetio je dijelove drvene brodske konstrukcije i veću količinu kamenja akumuliranu na jednome mjestu. ${ }^{7}$ Godine 1966. tadašnji kustos Arheološke zbirke u Ninu, Zdenko Brusić, zahvaljujući Kolanovićevoj je informaciji ušao u trag prvoj srednjovjekovnoj brodici (Nin 1), a dvije godine kasnije, tridesetak metara dalje, pronašao je i drugu (Nin 2). ${ }^{8}$

Dva plovna objekta, ispunjena kamenjem i očigledno namjerno potopljena pred ulazom u unutrašnju ninsku lagunu, ležala su na dubini od svega 1,5 - 2 m. Godine 1969. prva je brodica nacrtno dokumentirana u mjerilu 1:10, ${ }^{9}$ a 1973. na isti je način dokumentirana i druga. Već pri dokumentiranju 1969. pokazalo se kako nije riječ o klasičnoj brodskoj konstrukciji koja se odlikuje centralnom kobilicom. ${ }^{10}$ Umjesto nje, na dno je bila postavljena kobilična daska, a duž njenih su rubova s vanjske strane brodskoga korita bile pričvršćene dvije tanke i gotovo paralelne uzvojne kobilice. Riječ je o elementima koji se i danas koriste za stabilizaciju brodova, a pričvršćuju se na brodski trup na mjestu gdje dno prelazi u bok (uzvoj). Iako utječu na povećanje hidrodinamičkog otpora plovila, njihova je prednost što, pričvršćene izvana, ne utječu na unutrašnji raspored elemenata u brodskoj konstrukciji. O ostalim funkcijama uzvojnih kobilica ninskih brodica bit će govora u daljnjem tekstu.

Zahvaljujući zalaganju voditelja istraživanja, te trudu i podršci konzervatora Božidara Vilhara i njegovih suradnika, obje su brodice 1974. godine uspješno podignute s morskog dna. ${ }^{11}$ Akcija je potrajala deset dana, a sastojala se od zasebnog podizanja svakog rebra, platica i ostalih elemenata brodske konstrukcije (pramčana statva, kobilična daska, uzvojne kobilice, vršna proveza, temeljnica jarbola, nosači vesala i bitve), pri čemu su svi izvađeni elementi fotografirani i nacrtno dokumentirani u mjerilu 1:1, prema strogim pravilima struke. ${ }^{12}$

Brodica Nin 1 bila je očuvana u ukupnoj dužini od 6,68 m i najvećoj širini od 1,46 m. U trenutku otkrića zabilježeno je 26 rebara koja su uključivala 3 pramčana vijenca, 19 rebara sastavljenih od rebrenica i rebrenih nastavaka te 4 krmene rebrenice, ali se njihov ukupan broj do trenutka vađenja smanjio za 5 čitavih rebara i 7 ulomaka. Oplata se sastojala od 75 zasebnih

\footnotetext{
${ }^{5}$ Franc. archéologie navale; tal. archeologia navale; eng. nautical archaeology. Zahvaljujem prof. dr. sc. Vladimiru Skračiću i doc. dr. sc. Nikoli Vuletiću s Odjela za francuske i iberoromanske studije Sveučilišta u Zadru na velikoj pomoći pri odabiru najprikladnijeg termina na hrvatskom jeziku.

${ }^{6}$ Inicijativu autorice teksta podržali su prof. dr. sc. Zdenko Brusić, Radomir Jurić, kustos arheološkog muzeja u Zadru, i Mate Radović, voditelj Muzeja ninskih starina.
}

\author{
7 Z. BRUSIĆ, 1969, 443. \\ ${ }^{8}$ Z. BRUSIĆ, $1978,5$. \\ ${ }^{9}$ Z. BRUSIĆ, 1969. \\ ${ }^{10}$ Z. BRUSIĆ, 1969, 445, T. I. \\ ${ }^{11}$ B. Vilhar boravio je 1968/1969. na studijskom boravku \\ u Švedskoj i Danskoj kako bi se upoznao s postupkom \\ konzerviranja mokrog drveta. B. VILHAR, 1973. \\ ${ }^{12}$ Z. BRUSIĆ, 1974; B. VILHAR, 1974.
}


komada, debljine 2-2,8 cm, dok je kobilična daska bila nešto veće debljine. Na nju se nastavljala pramčana statva, a pretpostavka je da se sličan element nalazio i u krmenom dijelu broda. Dimenzije spomenutih uzvojnih kobilica, izrađenih od 2-3 komada drveta, iznosile su u presjeku 5 x $5 \mathrm{~cm}$.

Sveukupna dužina očuvanog dijela brodice Nin 2 iznosila je oko 6,3 m, a najveća širina 1,61,7 m. Sudeći prema očuvanim elementima, njena je originalna dužina bila oko 1,5-2 m veća nego li dužina brodice Nin 1, ne prelazeći pri tome sveukupnu dužinu od oko $9 \mathrm{~m}$. Pronađeno je jedno dislocirano i 20 rebara in situ, sastavljenih od 43 komada rebrenica i rebrenih nastavaka. Oplata se sastojala od 103 cjelovite ili oštećene platice, a osim nje izvađena je i kobilična daska, uzvojne kobilice, te temeljnica jarbola koja se nalazila između petog i šestog rebra u pramčanom dijelu broda. Među dislociranim elementima pronađeni su i ulomci vršne proveze, nosača vesala i bitvi.

Postupak desalinizacije drvene građe potrajao je dvije godine, nakon čega je drvo tijekom četrnaest mjeseci tretirano otopinom polietilen-glikola (PEG 4000). ${ }^{13}$ Riječ je o metodi koja se s promjenljivim uspjehom i danas najčešće koristi pri konzerviranju mokrog drveta. Po završetku konzervatorskog tretmana, svi su elementi brodske konstrukcije postupno osušeni i zamotani u plastične folije u očekivanju daljnje obrade.

Postupak rekonstrukcije započeo je u adaptiranoj prostoriji budućeg Muzeja ninske baštine 1981. godine, a potrajao je više od deset godina. Brodica Nin 1 rekonstruirana je u stanju u kakvom je pronađena na morskome dnu (Sl. 1), a brodica Nin 2 pokušaj je rekonstrukcije plovnog objekta u cjelini (Sl. 2). Rekonstrukcija je ostvarena u posebno pripremljenim nosačima, izrađenim od željeznih traka, koje je na osnovi brodskih linija projektirao Božidar Vilhar. Deformirani drveni elementi grijani su i vraćani u prvobitan oblik uz pomoć već spomenutih nacrta u mjerilu 1:1, kojima se nažalost do danas izgubio svaki trag. Gubitak nacrta onemogućuje nam danas dokumentirati i proučiti originalne spojeve izvedene uz pomoć drvenih i metalnih čavala, ${ }^{14}$ jer su za potrebe međusobnog spajanja elemenata tijekom rekonstrukcije korištene ne samo rupe od starih čavala, već i mnoge nove, a čitava unutrašnjost brodica zalivena otopinom polietilenglikola kako bi se konstrukcije učvrstile i simulirao originalni zaštitni sloj smole. ${ }^{15}$

Kad je u pitanju datiranje nalaza, valja upozoriti na još jedan podatak koji se nedavno pojavio u stručnoj literaturi. ${ }^{16}$ Riječ je o dendrokronološkom datiranju ninskih uzoraka u vrijeme između 571. i 729. godine, koje je na osnovi novih rezultata usmeno demantirano od strane sudionika projekta. ${ }^{17}$ Vrijedi, međutim, spomenuti kako je 1987. godine pet uzoraka hrastovine s ninskih brodica dendrokronološki datirano u vrijeme između 1152. i 1276. godine, ${ }^{18}$ što nam sugerira nešto kasnije vremensko određenje nalaza i poklapa se s mišljenjem stručnjaka za srednjovjekovnu brodogradnju koji konstrukcije ninskih brodova povezuju s odlikama brodogradnje trinaestog ili četrnaestog stoljeća. ${ }^{19}$

Dolazak pape Ivana Pavla II. u Hrvatsku 1994. godine potaknuo je izradu prve brodice po uzoru na ninske nalaze, koju je, u malom privatnom brodogradilištu u Betini, izradio majstor Čedomir (Ćiro) Burtina. Nekoliko godina kasnije izrađena je i druga. Valja svakako naglasiti

\footnotetext{
${ }^{13}$ M. JURIĆ, S. OGUIĆ, B. VILHAR, 1982; M. JURIĆ, S. OGUIĆ, B. VILHAR, 1994; M. JURIĆ, 1994.

${ }^{14}$ Spojevi se spominju u literaturi, ali iz razumljivih razloga nisu zabilježeni u postojećim nacrtima u mjerilu 1:10. Među objavljenom dokumentacijom ostao nam je zabilježen jedan detalj spajanja rebra, platice i uzvojne kobilice uz pomoć drvenoga čavla: Z. BRUSIĆ 1978, Fig. 4; Pl. IX.4.
}

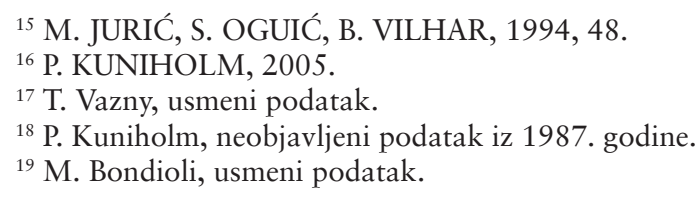




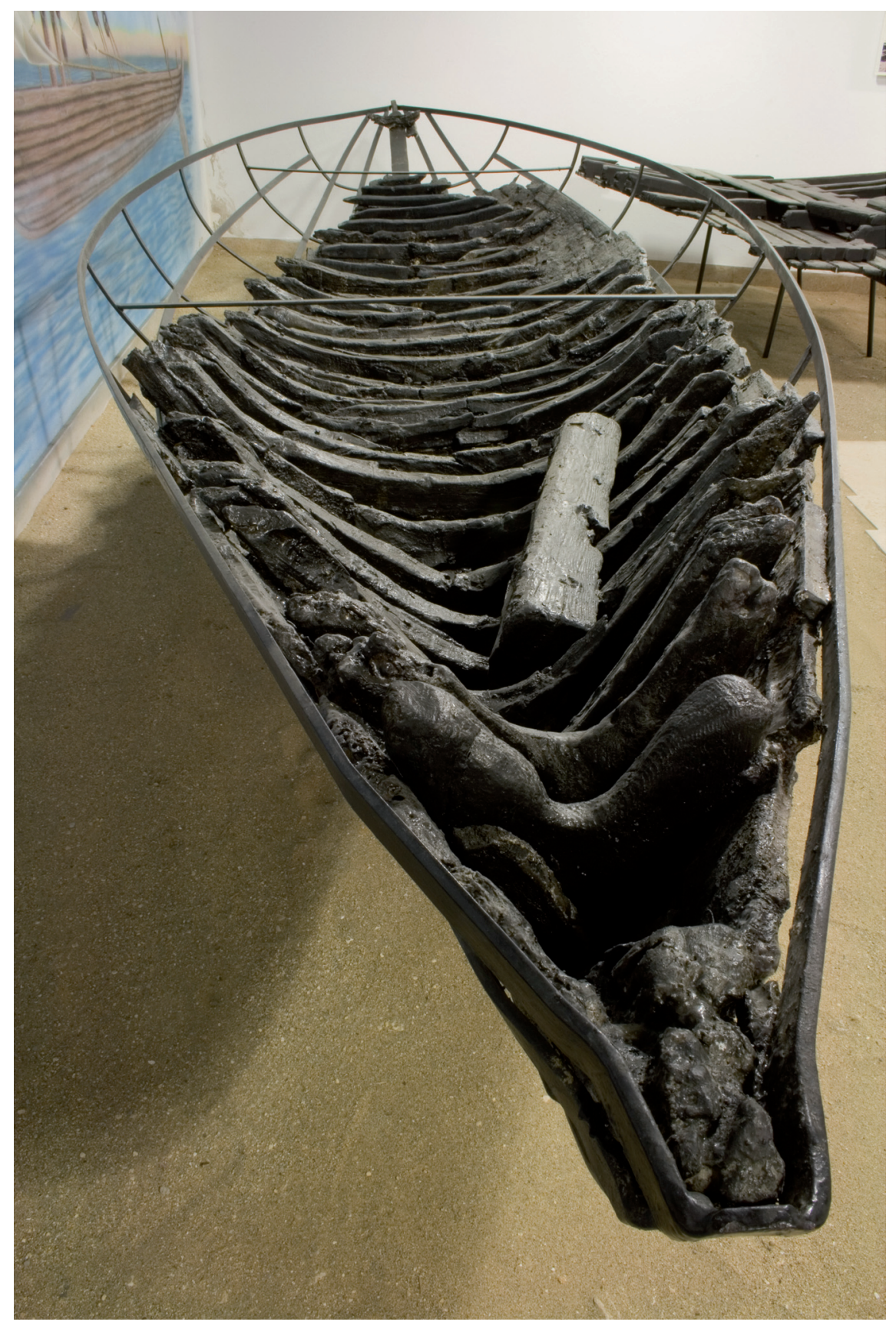

Sl. 1. Današnje stanje brodice Nin 1 u Muzeju ninske baštine (foto: R. Mosković). Fig. 1. Present state of the vessel Nin 1 in the Museum of Nin Heritage (photo: $R$. Mosković).

kako nije riječ o vjernim replikama srednjovjekovnih nalaza, već o brodicama inspiriranim rekonstrukcijama predloženima u Muzeju. Brodograditelju je svjesno ostavljena sloboda njihove izrade na tradicionalan način, prije svega zbog nedovoljno proučenog brodograđevnog umijeća srednjovjekovnih majstora iz Nina, ali i pionirskog iskustva u pokušaju izrade plovećih replika zasnovanih na arheološkim nalazima. 


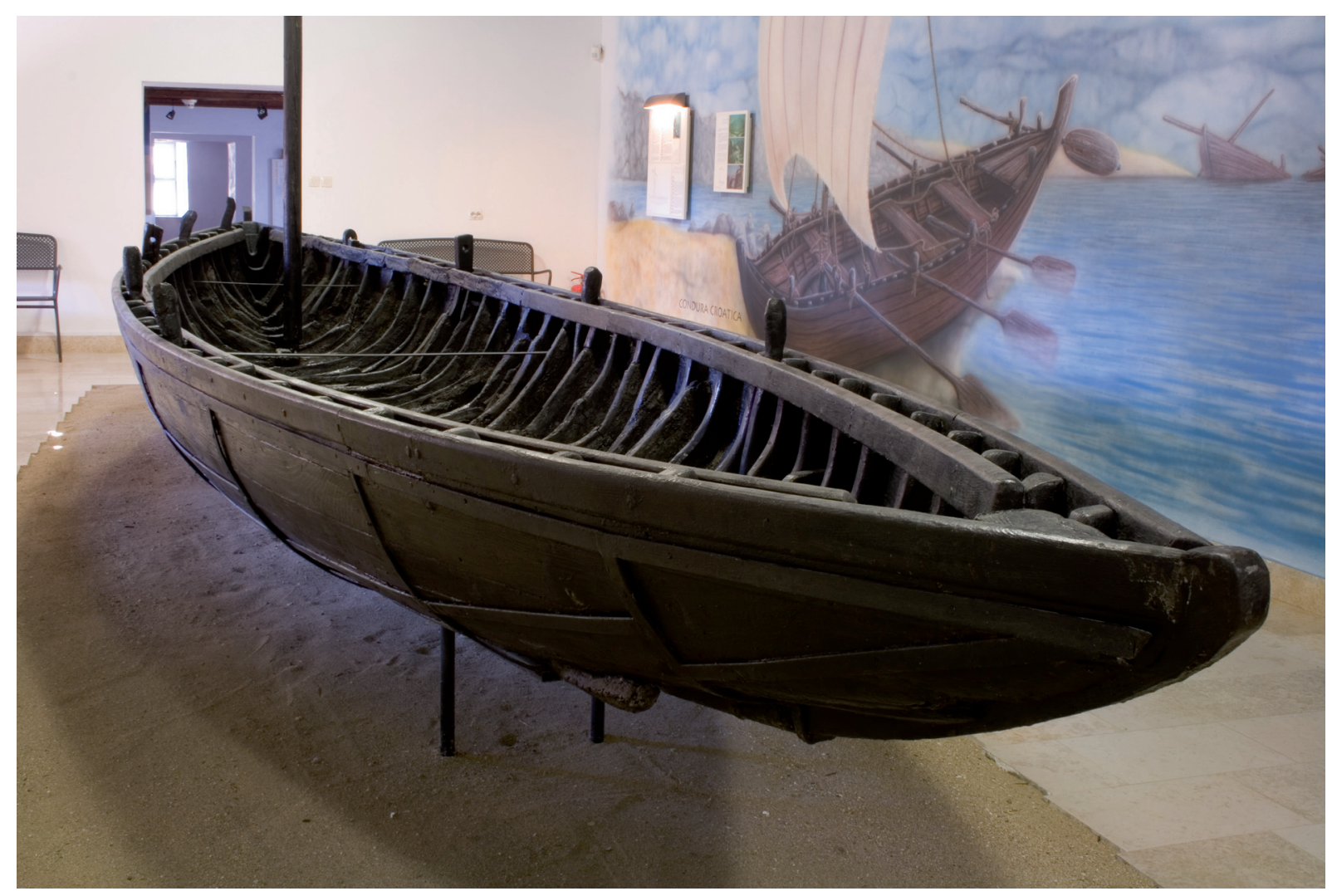

Sl. 2. Današnje stanje brodice Nin 2 u Muzeju ninske baštine (foto: R. Mosković).

Fig. 2. Present state of the vessel Nin 2 in the Museum of Nin Heritage (photo: R. Mosković).

\section{MATERIJAL I METODE ANALIZE UZORAKA DRVENE GRAĐE ${ }^{20}$}

Za potrebe uzimanja uzoraka svi su elementi brodskih konstrukcija označeni odgovarajućim oznakama. Zbog lakšeg razumijevanja među članovima međunarodne stručne ekipe, oznake su formirane kao kratice engleskih termina koji se uobičajeno koriste u arheologiji broda i plovidbe. Nemogućnost jasnog razlikovanja platica, zbog velike količine polietilen-glikola i ponekad nedovoljno prepoznatljivih suvremenih umetaka kojima su nadomješteni nedostajući dijelovi, uzrokovala je podjelu oplate u tri zone s obje strane kobilične daske. Iz svake zone uzorkovane su platice čiji je izgled upućivao na relativno dobru očuvanost drvene građe. Izdvojena je samo dokobilična platica, ali se po rezultatima analize i ona uklopila u preostali dio oplate.

Na brodici Nin 1 bilo je moguće relativno jasno razlikovati rebrenice i rebrene nastavke, što se ogledalo i u primijenjenim oznakama. Na brodici Nin 2 označavanje orebrenja predstavljalo je znatno teži zadatak, jer u mnogim slučajevima nije bilo jasno je li u pitanju oštećena rebrenica,

${ }^{20}$ Analizu drvene građe obavila je prof. dr. sc. Nili Liphschitz sa Sveučilišta u Tel Avivu. 
rebrenica nejednakih krakova, polurebrenica, rebreni nastavak, dvostruko rebro i sl. Stoga su rebra tretirana kao cjeline sastavljene od više elemenata, od kojih je svaki označen zasebnim brojem. Nacrtni i fotomozaički planovi nalaza na kojima su vidljive sve oznake omogućili su lakše snalaženje u dobivenim rezultatima.

Tijekom uzimanja uzoraka pokazalo se kako je tretirana drvena građa danas izrazito tvrda, a količina politetilen-glikola na mnogim mjestima daleko veća od očekivane, što je prouzrokovalo loše stanje očuvanosti originalne strukture drveta. Zbog toga je uzorkovanje zahtijevalo mnogo truda, ${ }^{21}$ a samo polovica uzoraka dala je pozitivne rezultate.

Prije uzorkovanja nepotrebni slojevi polietilen-glikola koji prekrivaju drvenu građu odstranjeni su grijanjem. Posebno debeli slojevi karakteristični su za unutrašnjost brodskog trupa obiju brodica. Oni su prije svega uzrokovani već spomenutim zalijevanjem otopinom PEGa 4000 prilikom rekonstruiranja nalaza, te dugogodišnjim premazivanjem istom otopinom koju je, u nedostatku drugačijih uputa, provodio muzejski majstor.

Uzorci su uzimani uz pomoć posebno pripremljenog cilindričnog svrdla izrađenog od metalne cijevi unutrašnjeg promjera $1 \mathrm{~cm}$, te ostalih pomoćnih alata poput skalpela i nožića različitih veličina. Iako se, sukladno važećoj metodologiji, nastojalo uzorkovati sve raspoznatljive elemente, pozitivan je rezultat u nekim slučajevima izostao. Na većim je elementima postupak bilo moguće ponoviti ukoliko se preliminarnom analizom pokazalo kako uzorak ne udovoljava kriterijima analize, dok je u slučaju elemenata manjih dimenzija neuspjeli uzorak uglavnom značio da se struktura drveta nepovratno izgubila u čitavome komadu. Prisutnost stručnjaka za analizu drveta prilikom uzimanja uzoraka pokazala se stoga višestruko korisnom, jer se uzorkovanje moglo odmah ponoviti ili na vrijeme od njega odustati. U slučaju brodice Nin 1 pozitivne je rezultate dao 61 uzorak (rebrenice, rebreni nastavci, pramčana statva, kobilična daska, uzvojne kobilice i platice), a u slučaju brodice Nin 2 broj pozitivnih uzoraka iznosio je 91 (rebrenice, rebreni nastavci, uzvojne kobilice i platice).

Uzorci su prokuhani u vodi kako bi ih se uklanjanjem polietilen-glikola učinilo mekšima, ali su i usprkos takvom postupku ostali pretvrdi za izradu presjeka. Kako se morfološkim pregledom pokazalo da je u većini slučajeva u pitanju hrastovina, trebalo je ukloniti tanin zbog kojega je drvo postalo tvrdim. To se postiglo natapanjem u $10 \%$ otopini klorovodične kiseline $(\mathrm{HCl})$ tijekom 24 sata, nakon čega je drvo omekšalo i postalo pogodnim za daljnju analizu. Poprečni, tangencijalni i radijalni presjeci (Sl. 4) napravljeni su oštrom britvom za svaki pojedini uzorak, nakon čega je uz pomoć mikroskopa određena vrsta drveta do razine roda i vrste. Kao usporedni materijal korišteni su presjeci sustavno identificiranog suvremenog drveća i grmlja te anatomski atlasi. ${ }^{22}$

\footnotetext{
${ }^{21}$ Uz autorice teksta, uzorkovanje su obavili Hrvoje Malinar, umirovljeni konzervator Hrvatskog restauratorskog zavoda, i Neven Lete, službenik tvrtke Geoarheo d.o.o. Koristimo priliku zahvaliti im na trudu i strpljenju kojim su znatno doprinijeli uspjehu akcije.
}

22 Podatci o današnjoj rasprostranjenost pojedinih vrsta na području zapadnoga Balkana preuzeti su iz Č. ŠILIĆ, 1983; S. MATIĆ, 2000 i A.-Ž. LOVRIĆ, 2001. 

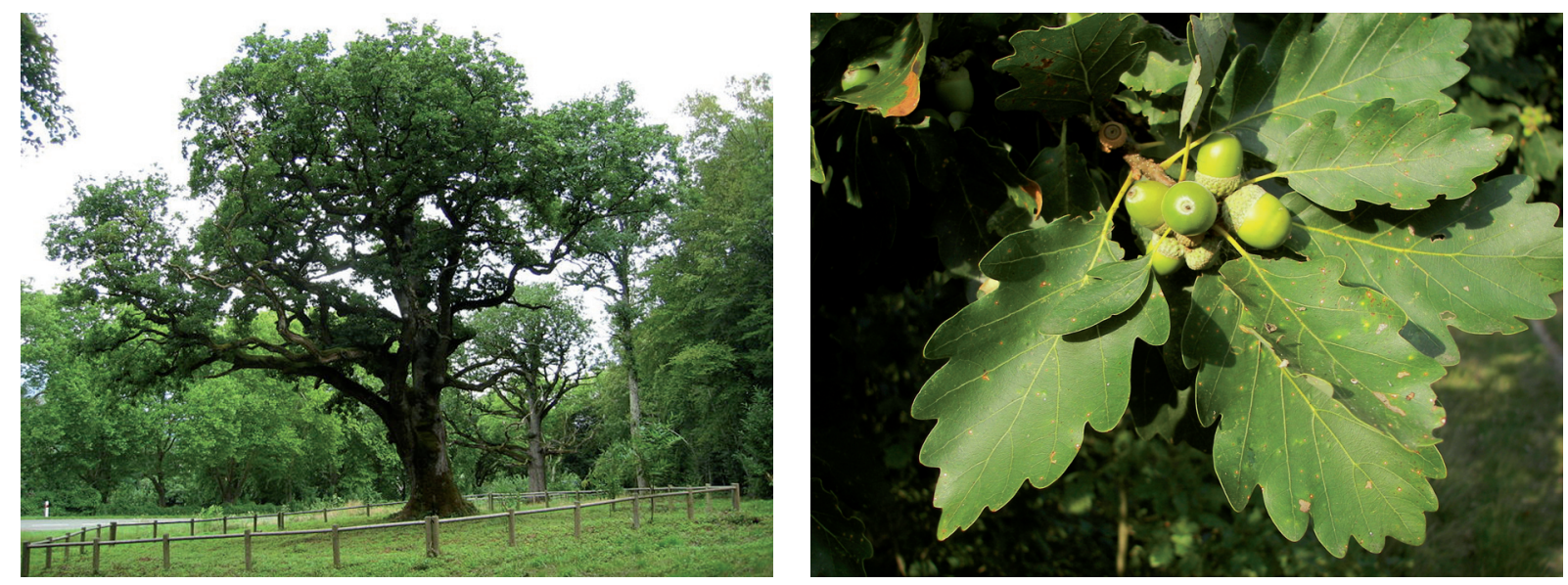

Sl. 3. Hrast kitnjak (Quercus Petraea) - a) stablo; b) list i plod.

Fig. 3. Sessile Oak (Quercus Petraea) - a) tree; b) leaves and acorns.
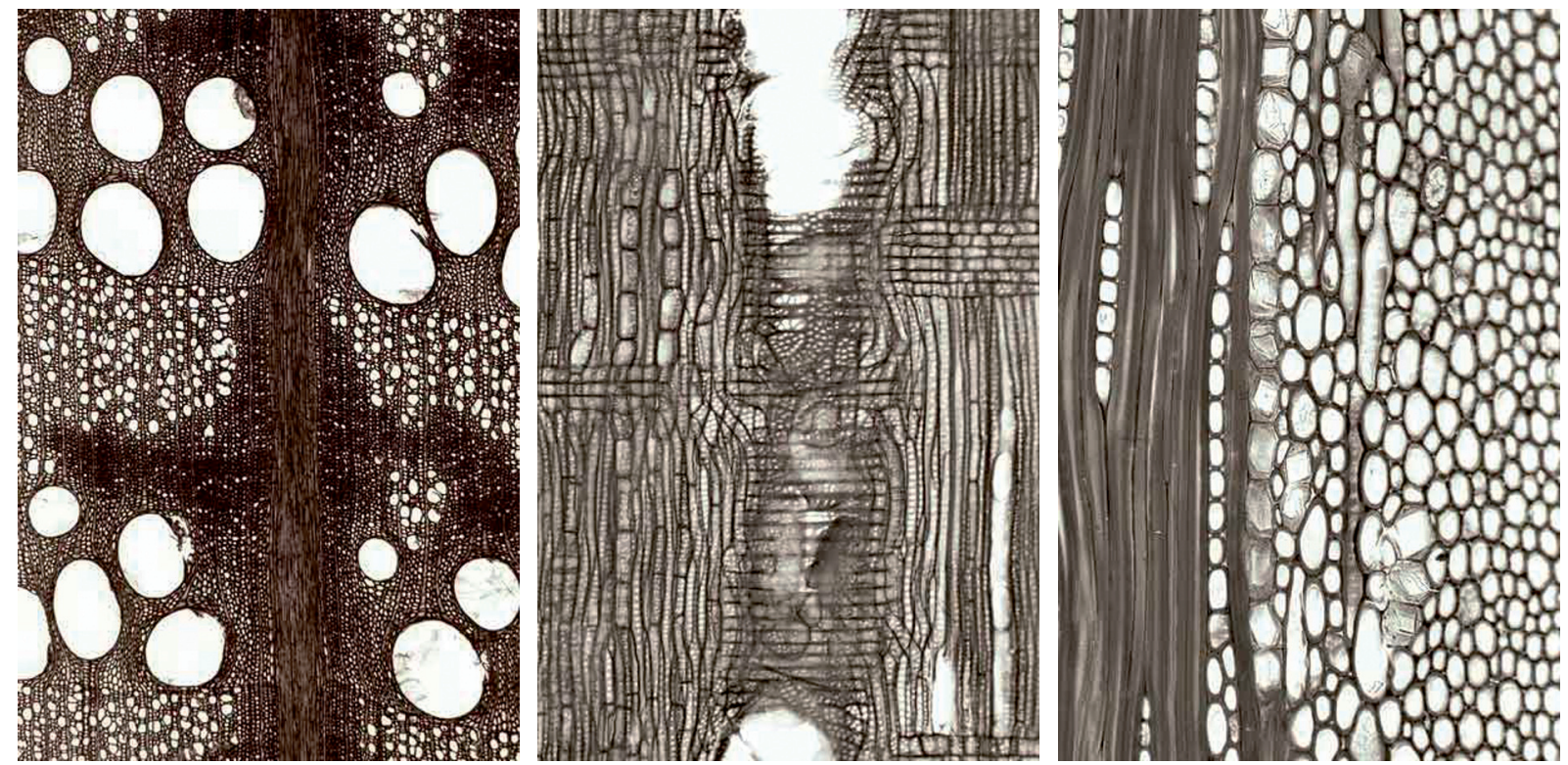

Sl. 4. Hrast kitnjak (Quercus Petraea) - a) poprečni presjek; b) radijalni presjek; c) tangencijalni presjek (bttp:// www.wFig.ch/land/products/dendro/species.php?.code=QUPE).

Fig. 4. Sessile Oak (Quercus Petraea) - a) cross-section; b) radial longitudinal section; c) tangential longitudinal section (http://www.wFig.ch/land/products/dendro/species.php?.code=QUPE).

\section{REZULTATI ANALIZE}

U slučaju brodice Nin 1 (T. 1), od ukupno 61 uzorka 43 ih je ukazalo na uporabu hrasta kitnjaka (Quercus petraea; Sl. 3), a 12 na uporabu hrasta cera (Quercus cerris; Sl. 5). Jedna je platica bila izrađena od istočne platane (Platanus orientalis), a jedna od poljskog brijesta (Ulmus campestris); četiri analizirana uzorka identificirana su kao obična jela (Abies alba). U slučaju 

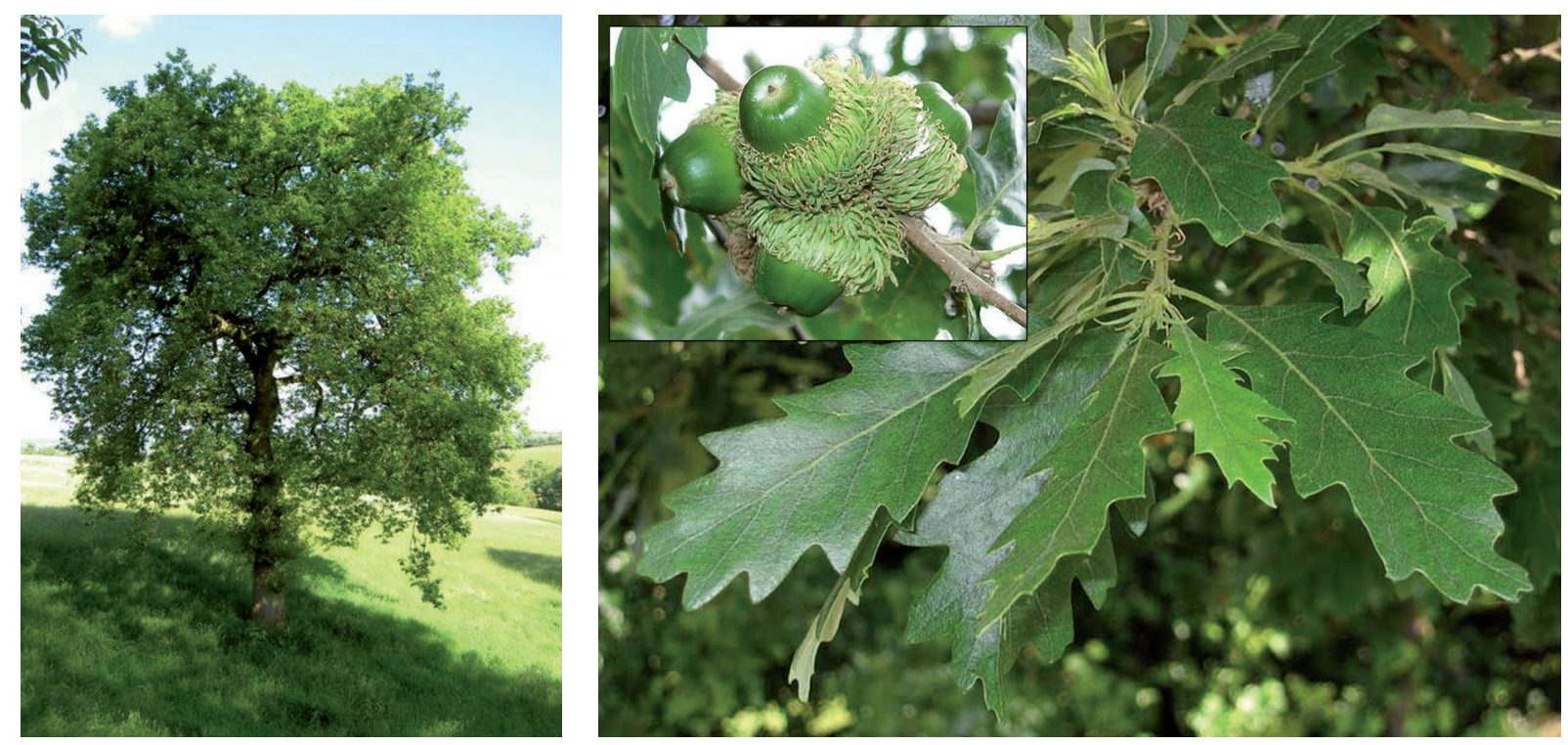

Sl. 5. Hrast cer (Quercus Cerris) - a) stablo; b) list i plod.

Fig. 5. Turkey Oak (Quercus Cerris) - a) tree; b) leaves and acorns.

brodice Nin 2 (T. 2), od ukupno 91 uzorka 84 su identificirana kao hrast kitnjak (Quercus petraea), 6 kao hrast cer (Quercus cerris), a jedan kao poljski brijest (Ulmus campestris).

Iz navedenoga proizlazi kako većina uzoraka ukazuje na hrast kitnjak kao osnovnu drvenu građu koroštena za gradnju ninskih brodica. Različiti dijelovi rebara i platice bili su većinom izrađeni od hrasta kitnjaka, uz povremeno korištenje hrasta cera. Mala količina uzoraka određenih kao cer sugerira nam mogućnost da je riječ o naknadnim popravcima pri kojima su dotrajali dijelovi brodica zamijenjeni novima, no u pitanju je pretpostavka koju na osnovi današnjeg stanja dokumentacije i nalaza ne možemo prihvatiti niti opovrgnuti. Od hrasta cera bila je izrađena i pramčana statva brodice Nin 1. Kako se pramčana statva druge brodice nije očuvala, nismo u mogućnosti donositi uopćenije zaključke o tom elementu brodske konstrukcije. Rijetki elementi izrađeni od istočne platane i poljskog brijesta također ukazuju na pretpostavku o naknadnim popravcima i zamjeni dotrajalih dijelova, a svi uzorci identificirani kao obična jela ne djeluju staro i mogli bi predstavljati zamjensko drvo korišteno prilikom suvremene rekonstrukcije nalaza.

Analizirani dijelovi uzvojnih kobilica obje brodice ukazali su također na korištenje hrasta kitnjaka. Takav podatak ne poklapa se s uvjerenjem istraživača, zasnovanom na intenzivnom mirisu smole primijećenom tijekom istraživanja i transporta, da je riječ o borovini. Teško je danas reći što je uzrokovalo spomenuti miris, ali je moguće da ga je izazvao akumulirani tanin ili smola kojom je bila zaštićena drvena građa. Probni uzorci pokazali su kako je struktura drveta od kojega je izrađena temeljnica jarbola gotovo potpuno uništena, pa više nije bilo moguće odrediti koje je drvo korišteno za njezinu izradu. 


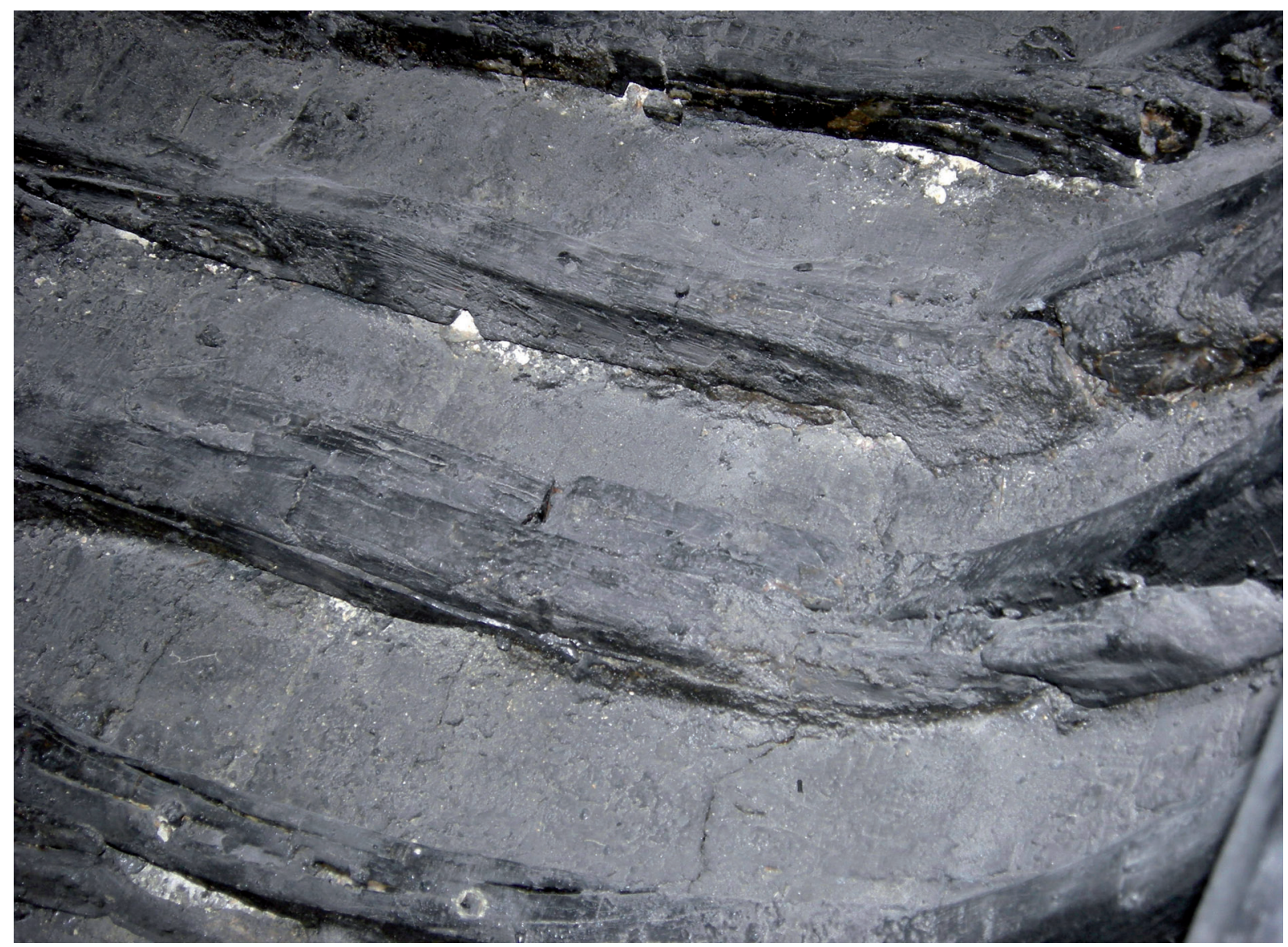

Sl. 6. Posljedice destruktivnih procesa koji su zabvatili konzervirane nalaze (foto: V. Frka).

Fig. 6. Consequences of destructive processes that affected conserved finds (photo: V. Frka).

Obje vrste hrasta potvrđene analizom uzoraka pripadaju skupini listopadnog drveća, što znači da je njihovo unutrašnje tkivo uspavano tijekom hladnih zimskih mjeseci. Na uzorcima obje vrste primijećene su dvije zanimljive osobine: izrazito uski godovi i naglašeni prsten širokih traheja u početku svakoga od njih, te godovi sastavljeni od vlakana izrazito debelih stijenki s malim staničnim lumenom. Obje osobine upućuju na činjenicu kako je riječ o drveću koje je raslo na području visokih planina, gdje su zime izrazito hladne. Takvo je drveće znatno čvršće i manje oštećeno djelovanjem nametnika, što ga čini prikladnim za korištenje u brodogradnji.

Obnovljeno zanimanje za ninske brodove nakon višegodišnje je stanke potaklo i pitanje njihove dugoročne konzervacije. Nestabilni mikroklimatski uvjeti u Muzeju ninske baštine i niz reakcija među starim i novim materijalima koji su ugrađeni u brodice i njihova postolja, doveli su do destruktivnih procesa koji se očituju u pojavi velike količine bijeloga praha kao posljedice raspadanja drveta i metala $($ Sl. 6,7$)$. Dugogodišnjim fizičkim uklanjanjem praha i premazivanjem otopinom polietilen-glikola uklanjale su se samo posljedice propadanja brodskih konstrukcija, dok su uzroci ostali nepoznati. $\mathrm{Na}$ osnovi mnogih primjera u svijetu, konzerviranje mokrog 

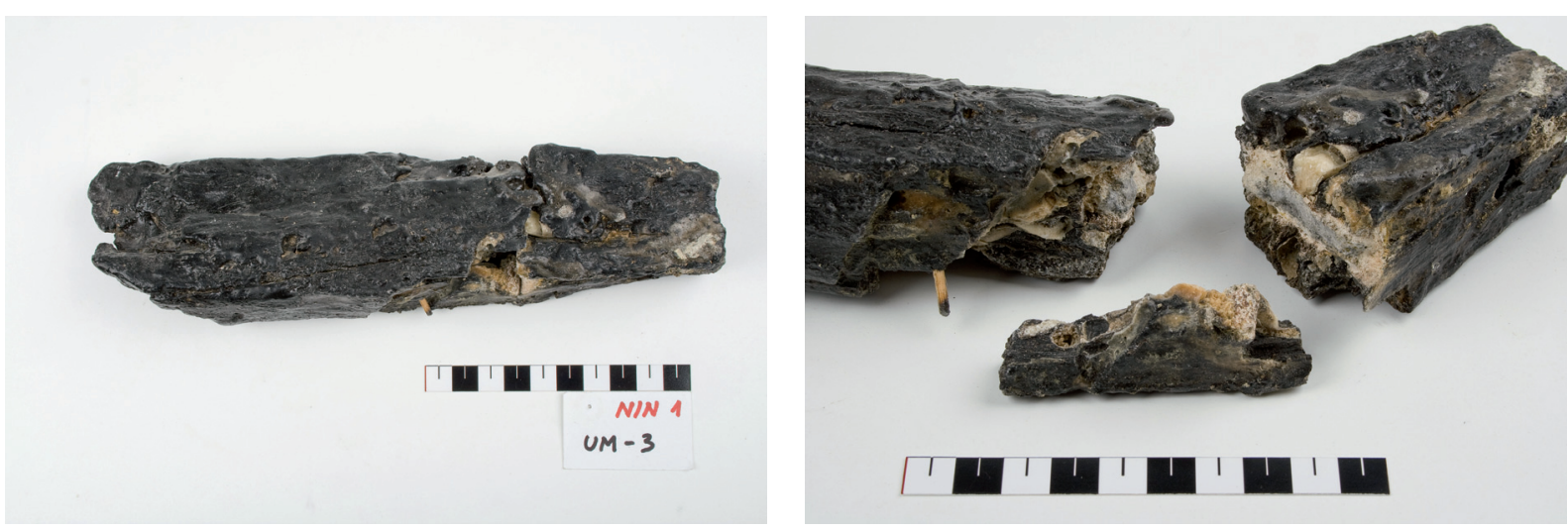

Sl. 7. Primjer propadanja konzerviranog materijala na dislociranom ulomku rebra (foto: $R$. Mosković).

Fig. 7. Example of degradation of treated materiel on a dislocated frame fragment (photo: R. Mosković).

drveta polietilen-glikolom predstavlja trajni proces koji se kontinuirano nastavlja i nakon samog postupka impregnacije. Stoga je nužno provesti detaljnu analizu stanja konzervirane drvene građe i postupno ukloniti uzroke njezinoga propadanja. ${ }^{23}$

\section{ZAKLJUČAK}

Područje prirodne rasprostranjenosti hrasta kitnjaka i hrasta cera uglavnom se poklapa. ${ }^{24}$ Hrast kitnjak jedna je od pet autohtonih vrsta hrasta na prostoru Hrvatske i pokriva oko 11\% sveukupne šumske površine. ${ }^{25}$ Hrast cer pojavljuje se uglavnom u malim šumskim zajednicama, u sub-mediteranskim i kontinentalnim područjima. ${ }^{26}$ Stoga kitnjak ima daleko veću ekonomsku vrijednost nego li cer.

U današnje vrijeme čak 19 različitih vrsta hrasta raste na području Dalmacije, uključivo i vrste iskorištene za izradu ninskih brodica. ${ }^{27}$ One su, doduše, prisutne samo u manjim zajednicama, no situacija u prošlosti bila je vjerojatno bitno drugačija. Iako za sada ne postoje detaljne analize dalmatinskog paleo-krajolika, sudeći prema pisanim izvorima možemo pretpostaviti kako je rasprostranjenost hrastovih šuma tijekom antičkog i srednjovjekovnog doba bila daleko veća nego li danas. ${ }^{28}$ Krajem 11. st., u vrijeme Prvog križarskog rata, tirski je biskup Wilhelm opisao prolaz križara kroz guste dalmatinske šume, i očuvao nam uspomenu na obilje drvene građe kojom se odlikovala srednjovjekovna Dalmacija. ${ }^{29}$

\footnotetext{
${ }^{23}$ Ulipnju 2010. poduzeta je prva konkretna akcija usmjerena na analizu postojećega stanja brodica i uzroka njihovoga propadanja. Akcija se ostvaruje u suradnji Sveučilišta u Zadru, Sveučilišta Texas A\&M (College Station, SAD) i Arheološkog muzeja u Zadru.
}

${ }^{24}$ Č. ŠILIĆ, 1983, 46, 48.

${ }^{25}$ S. MATIĆ, 2000, 6-8.

${ }^{26}$ S. MATIĆ, 2000, 10.

${ }^{27}$ A.-Ž. LOVRIĆ, 2001.

${ }^{28}$ B. POPARIĆ, 1901; M. NIKOLANCI, 1989.

${ }^{29}$ F. RAČKI, 1877, 462. 


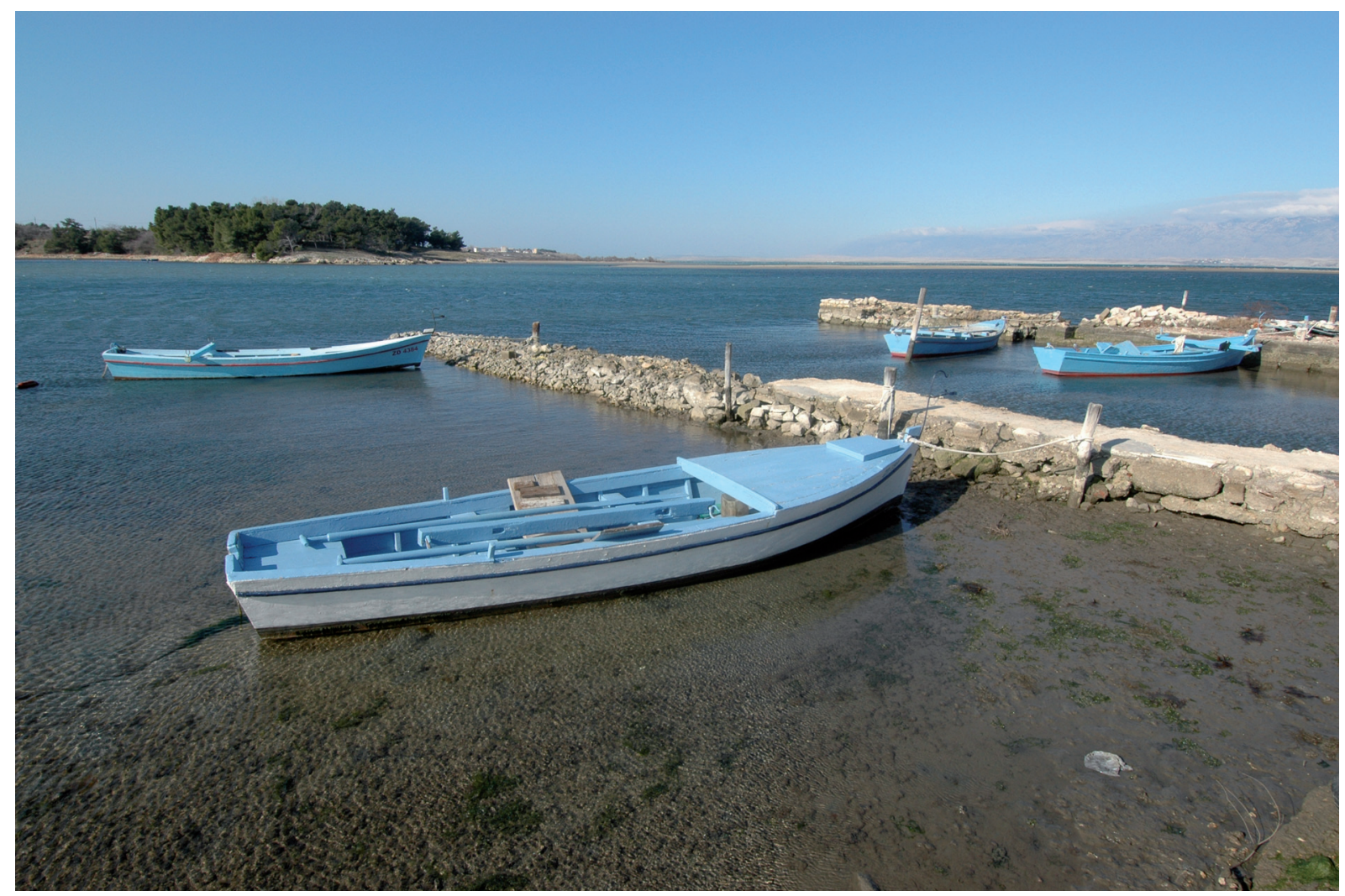

Sl. 8. Ninski kaić (batela) nasukan u plićaku u vrijeme oseke (foto: I. Radić Rossi).

Fig. 8. Traditional boat of Nin (ninski kaić, batela) during low tide (photo: I. Radić Rossi).

Uzimajući u obzir navedene činjenice možemo zaključiti kako su ninske brodice rad lokalnih majstora koji su koristili drvenu građu s viših padina Velebita ili velebitskog zaleđa. Jesu li, međutim, u to vrijeme priobalne padine već oskudijevale kvalitetnim drvetom ili su ninski brodograditelji namjerno odabrali drvo iz hladnije klimatske zone, za sada ostaje otvorenim pitanjem. Rezultati provedenih analiza dodatna su potvrda pretpostavci o lokalnom podrijetlu srednjovjekovnih nalaza iz Nina, na što prije svega upućuju osobitosti brodskih konstrukcija. Nedostatak centralne i postojanje dviju uzvojnih kobilica, namijenjenih stabilizaciji plovila, zaštiti trupa prilikom izvlačenja na pješčanu obalu te njegovom održavanju u uspravnom položaju za vrijeme oseke koja i danas domaće brodice ostavlja na suhom (S1. 8), svojstveni su upravo plitkoj i pjeskovitoj ninskoj laguni u kojoj se tradicija izrade plovnih objekata bez kobilice zadržala do naših dana.

Usprkos problemima izazvanim nepostojanjem originalne dokumentacije u mjerilu 1:1, rad na znanstvenoj obradi ninskih nalaza kao rijetkih i iznimno vrijednih svjedočanstava o srednjovjekovnom hrvatskom pomorstvu potrebno je nastaviti, vodeći svakako računa o postojećem stanju nalaza te potrebi hitne intervencije kada je riječ o njihovoj zaštiti. 


\begin{tabular}{|l|l|c|l|}
\hline \multicolumn{1}{|c|}{ Konstruktivni element } & \multicolumn{1}{|c|}{ Vrsta drveta } & Broj uzoraka & \multicolumn{1}{c|}{ Opaska } \\
\hline rebrenica & Abies alba & 3 & recentna građa \\
\hline & Quercus petraea & 4 & \\
\hline & Quercus cerris & 2 & \\
\hline rebreni nastavak & Quercus cerris & 2 & \\
\hline pramčana statva & Quercus cerris & 1 & \\
\hline uzvojna kobilica, lijeva & Quercus petraea & 4 & \\
\hline uzvojna kobilica, desna & Quercus petraea & 3 & \\
\hline kobilična daska & Quercus petraea & 3 & \\
\hline platica, lijevi bok & Quercus petraea & 14 & recentna građa $(2)$ \\
\hline & Quercus cerris & 6 & \\
\hline & Platanus orientalis & 1 & \\
\hline & Ulmus campestris & 1 & \\
\hline platica, desni bok & Abies alba & 1 & recentna građa \\
\hline & Quercus petraea & 15 & \\
\hline & Quercus cerris & 1 & \\
\hline \multicolumn{2}{|c|}{ Sveukupni broj uzoraka } & 61 & \\
\hline
\end{tabular}

T. 1. Rezultati analize drvene građe (Nin 1).

Pl. 1. Wood species identification (Nin 1).

\begin{tabular}{|l|l|c|}
\hline \multicolumn{1}{|c|}{ Konstruktivni element } & \multicolumn{1}{|c|}{ Vrsta drveta } & Broj uzoraka \\
\hline $\begin{array}{l}\text { rebro } \\
\text { (rebrenica, rebrenica nejednakih } \\
\text { krakova, rebreni produžnik) }\end{array}$ & Quercus petraea & 19 \\
\hline & Quercus cerris & 3 \\
\hline uzvojna kobilica, lijeva & Quercus petraea & 3 \\
\hline uzvojna kobilica, desna & Quercus petraea & 3 \\
\hline platica, lijevi bok & Quercus petraea & 26 \\
\hline & Quercus cerris & 1 \\
\hline platica, desni bok & Quercus petraea & 32 \\
\hline & Quercus cerris & 2 \\
\hline \multicolumn{2}{|c|}{ Sveukupni broj uzoraka } & 1 \\
\hline neidentificirani uzorak & Ulmus campestris & 1 \\
\hline \multicolumn{2}{|c|}{} & Quercus petraea \\
\hline
\end{tabular}

T. 2. Rezultati analize drvene građe (Nin 2).

Pl. 2. Wood species identification (Nin 2). 


\section{LITERATURA}

BRUSIĆ, Z., 1969. - Zdenko Brusić, Podmorska arheološka istraživanja starohrvatskih brodova na ulazu u ninsku luku, Radovi Instituta JAZU u Zadru, 16-17, Zadar, 443-448.

BRUSIĆ, Z., 1974. - Zdenko Brusić, Podmorska arheološka istraživanja plovnih objekata na ulazu u Ninsku luku (Ždrijac), Arhivsko izviješće, Zadar.

BRUSIĆ, Z., 1978. - Zdenko Brusić, Rezultati najnovijih istražianja i vađenje starohrvatskih brodova na ulazu u ninsku luku, Adriatica Maritima, 2, Zadar, 5-14.

JURIĆ, R., 1994. - Radomir Jurić, Istraživanje i konzervacija ranohrvatskih brodova iz Nina, Kaštelanski zbornik, 4, Kaštela, 61-72.

JURIĆ, R., OGUIĆ, S., VILHAR B., 1982. - Radomir Jurić, Stošija Oguić, Božidar Vilhar, Konzervacija starohrvatskih brodova iz Nina, Almanah jugoslavenskog mediteranskog podneblja, 1, Rijeka, 281290.

JURIĆ, R., OGUIĆ, S., VILHAR, B., 1994. - Radomir Jurić, Stošija Oguić, Božidar Vilhar, Konzervacija i početak rekonstrukcije ranohrvatskih brodova iz Nina, Adrias - Zbornik Zavoda za znanstveni $i$ umjetnički rad HAZU u Splitu, 4-5, Split, 43-62.

KOLEGA, M., 2004. - Marija Kolega, Arheološki muzej Zadar - Muzej ninskih starina. Vodič, Zadar.

KUNIHOLM, P., 2005. - Peter Kuniholm, Aegean Dendrochronology Project December 2005, Progress Report, Cornell University. P. 5, item 24.

LOVRIĆ, A.-Ž., 2001. - Andrija-Željko Lovrić, Ekobotanički pregled hrastova u Istri na Sjevernom Jadranu, Bujština, Umag, 134-147.

MATIĆ, S. 2000. - Slavko Matić, Oak Forests (Quercus sp.) in Croatia, Glasnik za šumarske pokuse, 37, Zagreb, 1-14.

NIKOLANCI, M., 1989. - Mladen Nikolanci, Šume Dalmacije u antici, Vjesnik za arheologiju i historiju dalmatinsku, 82, Split, 157-168.

POPARIĆ, B., 1901. - Bare Poparić, Dalmatinske šume u historiji, Glasnik Matice Dalmatinske, 3, Zadar, 225-250.

RAČKI, F., 1877. - Franjo Rački, Documenta historiae Chroaticae periodum antiquam, Monumenta spectantia historiam Slavorum meridionalium, VII, Zagreb.

SRDOČ, D., SLIJEPČEVIĆ, A., BREYER, B., 1971. - Dušan Srdoč, Adela Slijepčević, Branko Breyer, Datiranje arheoloških nalaza biološkog porijekla metodom radioaktivnog ugljika C-14, Rad Jugoslavenske akademije znanosti i umjetnosti, 349, Zagreb, 109-147.

ŠILIĆ, Č., 1983. - Čedomil Šilić, Atlas drveća i grmlja, Sarajevo.

VILHAR, B., 1973. - Božidar Vilhar, Hidroarheološka iskustva Šveđana i Danaca - Konzervacija drva polyethilenglykolom, Pitanja zaštite hidroarheoloških spomenika kulture na području SR Hrvatske, radni sastanak, Dubrovnik, 12.-13. travnja 1973., Republički zavod za zaštitu spomenika kulture, Zagreb, 88-92.

VILHAR, B., 1974. - Božidar Vilhar, Pomorska arheološka istraživanja plovnih objekata na ulazu u Ninski zaljev (Ždrijac), Arhivsko izviješće, Zadar. 


\section{Medieval Boats from Nin: Wood Species Identification}

\section{SUMMARY}

Two boats (Nin 1 and Nin 2) were discovered in the 1960s at the entrance to Nin harbor, fifteen km northwest of Zadar. In 1974 the boats were lifted from the sea bed, were preserved in PEG and presented to the public in the Museum of Nin Heritage. According to radiocarbon evidence the boats date to the eleventh/twelfth century. They were about $8 \mathrm{~m}$ long and were built in skeleton first technique. The frames and planks were fastened together with nails and treenails. Instead of a central keel they were provided with a keel plank and two parallel bilge keels, which run below the garboards. A wooden base for the mast step was also found.

A sampling of the wooden elements to identify wood species was realized in 2008. Sixty-one samples were taken from various elements of the Nin 1 frames, futtocks, stem post, bilge keel, planks and central plank), and 91 samples were taken from Nin 2 (frames, planks, bilge keel and central plank). The majority of the components from both wrecks were made of Quercus petraea. In Nin 1, 43 of 61 samples were of Quercus petraea, and 12 samples were of Quercus cerris. One plank was made of Platanus orientalis, another of Ulmus campestris. Four analyzed components were identified as Abies alba and are probably modern insertions in the reconstruction. In Nin 2, 84 of 91 samples were made of Quercus petraea, 6 of Quercus cerris. One plank was identified as Ulmus campestris.

The native distribution area of Quercus petraea and Quercus cerris coincide. Both oak species are very common in Croatia and the Balkans. Anatomical features indicate that both species of oak that were used as construction timber for the Nin boats grew in a region characterized by high mountains and very cold winters, resulting in trees which are better fit for shipbuilding because of their strength and lack of insect and fungal damage. While it is logical to assume that local boatyards building small boats would have exploited local timber sources, or whatever was locally available, it is possible that such timbers were depleted in this region, thus forcing the procurement of timber from mountainous areas.

Key Words: boat, Middle Ages, underwater excavation, dendrological analysis, nautical archaeology

Prijevod / Translation: Nili Liphschitz 